\title{
Anaerobic Digester Variation on Wastewater Treatment
}

\author{
Elida Novita ${ }^{{ }^{*}}$, Hendra Andiananta Pradana ${ }^{2}$, Sri Wahyuningsih ${ }^{1}$, Bambang Marhaenanto ${ }^{1}$ and \\ Moh. Wawan Sujarwo ${ }^{2}$ \\ 1 Department of Agriculture Engineering, Faculty of Agricultural Technology, University of Jember, Jember \\ 68121, Indonesia \\ 2 Water Management of Agricultural, Master Program of Postgraduate, University of Jember, Jember 68121, \\ Indonesia (172520103004@students.unej.ac.id) \\ * Correspondence: elida_novita.ftp@unej.ac.id;+62811354686
}

\begin{abstract}
Wet coffee processing methods will produce wastewater containing organic matter. The high content of organic matter can be utilized as biogas through the anaerobic process. Anaerobic digesters construction can affect removal process of wastewater pollution and biogas quantity. The purpose of this study is to determine the effect of digester construction between conventional digester, CSTR and UASB producing biogas from coffee wastewater. The conventional digester worked without temperature control system as control, a UASB digester, and CSTR digester worked with temperature control system. Biomass volume was about $5 \mathrm{~L}$ with 35 days incubation time. Temperature and $\mathrm{pH}$ for UASB and CSTR were set within the range $30-35^{\circ} \mathrm{C}$ and $\mathrm{pH} 6.0-8.0$. Based on the feeding variations, UASB has a stable performance with $83.57 \mathrm{ml} /$ day of average biogas production. It has also highest remediation efficiency of $\mathrm{COD}, \mathrm{BOD}$ and $\mathrm{C} / \mathrm{N}$ with $85.00 \pm 0.34 \%, 84.40 \% \pm 5.66$ and $97.78 \pm 0.57$.
\end{abstract}

Keyword: anaerobic process; biogas; coffee wastewater; digester construction

\section{Introduction}

Coffee is one of Indonesia's leading commodities. National coffee production was estimated to reach 667 tons in 2016. Indonesia takes the fourth place of coffee producers and exporter in the world after Brazil, Vietnam and Colombia. Coffee beans are the result of processing from coffee fruit. One of the utilization or downstream of coffee beans is beverage products. There are three methods of coffee beans processing into coffee beans namely dry processing, semi-wet processing and wet processing. The semi-wet and wet coffee processing produces coffee beans with a better quality, but the wet method is relatively inhospitable [1].

Wet coffee processing requires $10-30 \mathrm{~m}^{3}$ of water per ton of coffee. Coffee wastewater has acidity level $(\mathrm{pH})$ at $3.0-5.0$. It is corrosive and has a high content of organic materials that can interfere aquatic life organisms if discharged directly to water bodies. The coffee wastewater can have a COD value between 3,100 - 14,343 mg / $\mathrm{L}$ and BOD between 5,000 - 35,000 $\mathrm{mg} / \mathrm{L}$. The high content of organic matters in coffee wastewater indicated by COD or BOD values can be utilized as biogas through anaerobic process, with cycles consisted of hydrolysis, acidification and methanogenesis (biomethanation). The anaerobic process will break down the pollutants into compounds that are relatively safer for the environment with a 50 to $90 \%$ reduction in the COD, BOD, TSS and TDS values [2]. It will produce methane gas for energy resources.

Biogas is produced through fermentation process using auxiliary microorganisms derived from cattle dung (ruminants), while the latter contains $\mathrm{C} / \mathrm{N}$ which is relatively optimal or stable at 24 . Cow dung addition can increase the success of biogas volume production [3]. Biomass input and biodigester 
construction can determine the quality and quantity of biogas. High concentrations of organic materials and stirring construction on digester can increase the activity of methanogenic bacteria [4] and [5]. Semi-continuous method is one of feeding or biomass feeding methods in anaerobic process. This method allows the feeding of raw materials in a certain period, so that biomass does not have to be available at any time [6]. Semi-continuous method for biogas production is easy to be applied by coffee farmers because it does not need to disassemble digester and has relatively low operational cost. In addition, this method allows for variations in the addition of biomass and inoculums over a period of time which makes biogas production stable. Therefore, the purpose of this research was to know the effect of input variation and construction of digester in the coffee wastewater treatment for biogas production by semi-continuous method.

\section{Material and Methods}

\subsection{Tools and Materials}

The instruments used in this research were a big bottle, $100 \mathrm{~mL}$ and $500 \mathrm{~mL}$ pyrex, $100 \mathrm{~mL}$ beaker glass and $500 \mathrm{~mL}$ with a brand pyrex, oven with a brand memmert, $\mathrm{pH}$ meter with a brand senz, $\mathrm{CO}_{2}$ meter GCH - 2018 with a brand Lutron, pH meter calibration check HI 223, USB downloader, computer peripheral, BASCOM AVR IDE Software version 2.0.7.7, COD reactor HI 839800 Hanna brand, HI 83099 spectrophotometer and Kjeldahl flask. The materials used in the research are coffee wastewater, anaerobic starter, aquadest, $\mathrm{NaOH} 1 \mathrm{~N}$ and $0.1 \mathrm{~N}, \mathrm{H}_{2} \mathrm{SO}_{4} 20 \mathrm{~N}, 40 \%$ sulfuric manganese, alkaline iodide azide, HR COD reagent (High Range) HI $93754 \mathrm{C}-25, \mathrm{Na}_{2} \mathrm{~S}_{2} \mathrm{O}_{3}$ 0,025 N, starch indicator 0,05 N, 1\% boric acid, methyl red indicator, $\mathrm{NaOH} 40 \%, \mathrm{HCl} 0,05 \mathrm{~N}, \mathrm{~K}_{2} \mathrm{Cr}_{2} \mathrm{O}_{7} 2 \mathrm{~N}$, ATMega8 microcontroller, LM35 temperature sensor, PCB board, $2 \times 16 \mathrm{LCD}$, relay, heater, crystal 8000, $100 \mathrm{k} \Omega$ and $1 \mathrm{k}$ res resistor, C828 transistor, $16 \mathrm{~V} 1 \mu \mathrm{F}$ capacitor, $1 \mathrm{~A}$ diode, $12 \mathrm{~V}$ adapter, 2 potassium, tin, 28 foot microcontroller socket, LED, cable, on / off switch, ic regulator 7805, iron hider, and pipe.

\subsection{Digester Design and Model}

There were three digester used in this research, namely digester (1) Conventional Model (CM), (2) Up Flow Anaerobic Sludge Blanket (UASB) and (3) Continuous Stirred Tank Reactor (CSTR) which can be seen in Figure 1. All digester was constructed using fiber material. UASB and CSTR with temperature control system. The total volume of each digester was 7.5 liters.

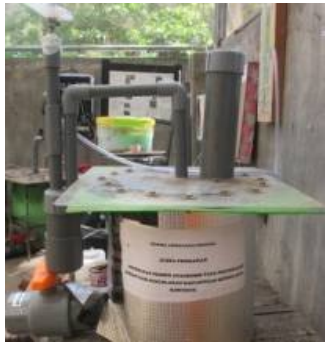

(a)

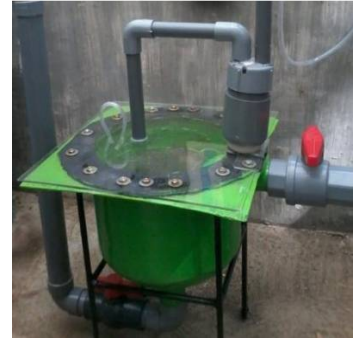

(b)

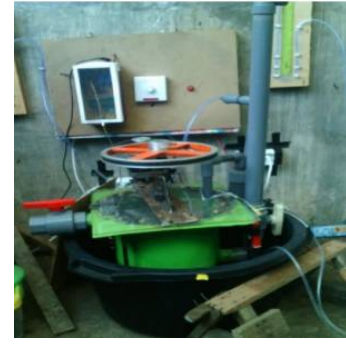

(c)

Figure 1. Rector model: (a) CM; (b) UASB and (c) CSTR

\subsection{Procedure Experiment and Parameter Analysis}

Initial characteristics of coffee wastewater include measurement of following parameters; temperature, $\mathrm{pH}, \mathrm{COD}, \mathrm{BOD}, \mathrm{C}$ and $\mathrm{N}$. In addition, daily parameters measurement of volume and biogas composition were performed for 35 days. And at the end of anaerobic process the measurements 
were made for COD, BOD, $\mathrm{C}$ and $\mathrm{N}$ parameters in every feeding. There were semi-continuous methods in batch feeding.

\subsubsection{Stage of Feeding Variation by Semi - Continuous Method}

The anaerobic process stages of coffee wastewater used a combination of batch and semi continuous methods. The feeding variation can be seen in Table 1. The majority of the effluent in the form of slurry in the digester is not excreted and reused for incubation to the next stage. The total solution or biomass on the three digesters remains 5 liters at each incubation stage. The previous slurry/effluent was assumed to be starter.

Table 1. Feeding variation in CM, UASB and CSTR used semi - continuous method

\begin{tabular}{|c|c|c|c|c|c|c|}
\hline \multicolumn{7}{|c|}{ Phase } \\
\hline & & & 1 & 2 & 3 & 4 \\
\hline \multirow{12}{*}{ 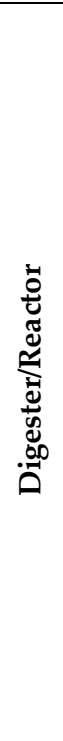 } & \multirow{4}{*}{$\mathrm{CM}$} & CW (L) & 1.60 & 0.80 & 0.24 & 0.48 \\
\hline & & $C(\mathrm{~L})$ & - & - & 0.24 & - \\
\hline & & $\mathrm{E}(\mathrm{L})$ & 3.40 & 4.20 & 4.52 & 4.52 \\
\hline & & VT (L) & 5.00 & 5.00 & 5.00 & 5.00 \\
\hline & \multirow{4}{*}{ UASB } & $\mathrm{CW}$ & 1.00 & 1.00 & 0.50 & 1.00 \\
\hline & & C & - & - & 0.50 & - \\
\hline & & $\mathrm{E}$ & 4.00 & 4.00 & 4.00 & 4.00 \\
\hline & & VT & 5.00 & 5.00 & 5.00 & 5.00 \\
\hline & \multirow{4}{*}{ CSTR } & $\mathrm{CW}$ & 0.60 & 0.60 & 0.30 & 0.60 \\
\hline & & C & - & - & 0.30 & - \\
\hline & & E & 4.40 & 4.40 & 4.40 & 4.40 \\
\hline & & VT & 5.00 & 5.00 & 5.00 & 5.00 \\
\hline & (Days & & 14 & 7 & 7 & 7 \\
\hline
\end{tabular}

CW: Coffee Wastewater; C: Cow Dung; E: Effluent; VT: Volume Total, Volume total of biomass in CM, UASB and CSTR was $5 \mathrm{~L}$

\subsubsection{Stage of Feeding Variation by Semi - Continuous Method}

Data was performed in two ways, daily data and data comparison from beginning and ending process. Daily data observed includes the volume and composition of biogas formed, $\mathrm{pH}$ and temperature. Daily data processing were done using Ms. Excel with a graph output that has independent parameters ( $\mathrm{x}$ axis) in the form of time and parameter dependent (y point) in the form of water and gas quality parameters. The data processing of the research was done on parameters measured at the beginning and at the end of each batch feeding which includes COD, BOD and C/N. The method of data processing was done by determining the percentage of decrease level of pollution parameter. The determination of the decreased pollution percentage level of wastewater of coffee was done to know the level of decreasing parameter of coffee wastewater at CM, UASB and CSTR using semi-continuous method. The following is the percentage equation for the decrease in pollution levels. 
Efficiency $=\frac{\text { Concentration 2-Concentration } 1}{\text { Concentration } 2} \times 100 \%$

\section{Result and Discussion}

\subsection{Analysis of Biogas Parameters}

\subsubsection{Production of Biogas Volume}

The anaerobic process has two advantages. The advantages are to produce biogas that can be used as a source of energy and to decrease the pollutant concentration. Anaerobic process results are methane gas (biogas), carbon dioxide gas, hydrogen and sulfide hydrogen. Biogas is a fluid derived from microorganism activities in remodeling or degrading organic materials through aerobic or anaerobic processes. Anaerobic processes use oxygen as a barrier in biogas production. Oxygen does not function as electron acceptor in conducting degradation activity of organic matter [7]. Methanogenic bacteria that play a role in biogas formation utilize carbon as electron acceptor to produce methane gas as one of biogas component. Some of the bacteria predicted to play a role in the biogas formation cycle are hydrolytic (hydrolysis), acid / farming bacteria and acetogenic bacteria (acidity), Methanobacterium and Methanosarcina [8]. Characteristics or fluctuations in the formation of biogas will be influenced by the activity of microorganisms and environmental factors.

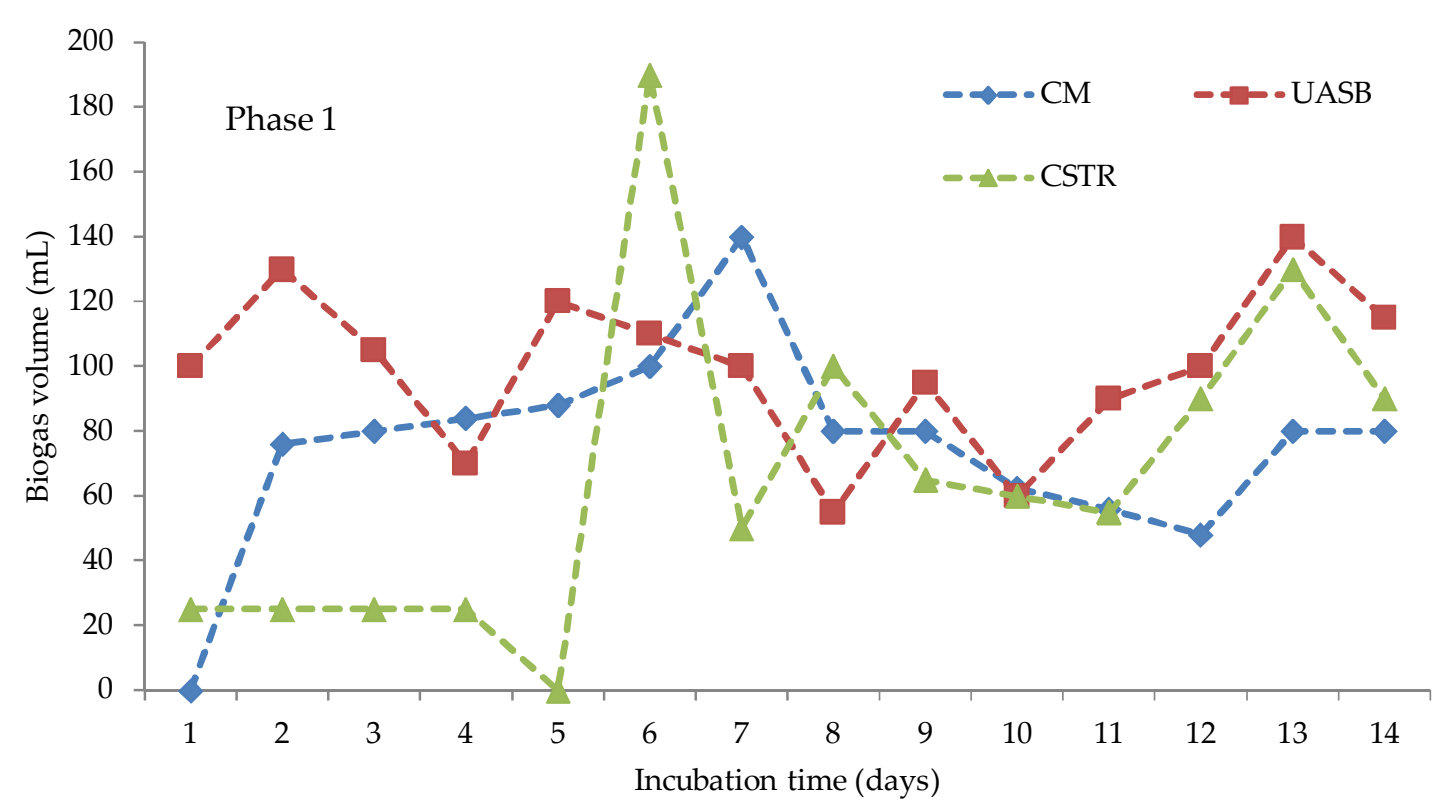

Figure 2. Biogas production used batch method in 14 days

Biogas volume fluctuations were presented in Figure 2. It explains the digester can affect the biogas production. The inoculums used in the anaerobic process of coffee wastewater are obtained from an active batch digester. The activity of methanogenic bacteria in cow dung culture is estimated to have a performance period of $2-14$ days in methane gas production [9]. Therefore, this study used a 14 day incubation period.

The duration of incubation is the same for conventional digesters, UASB, and CSTR which aims to find out the biogas pattern formed for 14 days with batch feeding method in phase 1 . The total volume of biomass and inoculums contained within each digester is 5 Liters. Conventional digester produces biogas with a range of values from 0 to $140 \mathrm{ml}$. UASB produced biogas volume with a range of values from 50 to $140 \mathrm{~mL}$. The CSTR produced biogas volume of $25 \mathrm{~mL}-190 \mathrm{~mL}$. Base on Figure 3. that biogas 
production at the highest point in phase 1 is UASB with $135 \mathrm{~mL}$ volume on day 2, CSTR with volume $190 \mathrm{ml}$ on day 6 , and conventional digester with volume $140 \mathrm{ml}$ on day 7 . The average production of conventional biogas digesters (CM), UASB and CSTR sequentially incubated for 14 days in $75.31 \mathrm{~mL} /$ day, $99.29 \mathrm{~mL} /$ day and $66.43 \mathrm{~mL} /$ day. Digester UASB has a more stable performance in biogas production than conventional digester and CSTR although the volumes of biogas produced are volatile. Fluctuations in biogas production on all three digesters are predicted to be influenced by the activity of anaerobic microorganisms [10]. The monody model is a model of fluctuations in the growth of aerobic or anaerobic microorganisms that can be used as a basis for microbial activity approaches in anaerobic processes [5].

Based on the adaptation of microorganisms that refer to the monod model, the activity of microorganisms in CM and UASB is predicted short lag phase and directly experience logarithmic stages, based on the volume of biogas produced on the day to 1 - day to 7 . While the activity of microorganisms in the digester CSTR predicted phase lag or slow growth and phase of death on day 1 5 then on day 6 reaches the highest point and predicted to experience exponential phase. The volume of biogas produced on days $8-14$ tends to fluctuate and predicted bacterial activity in the logarithmic phase - static occurs. UASB has the potential to produce better and more stable biogas volumes than conventional and CSTR digesters. UASB construction allows the hydrolysis of coffee wastewater was shorter, because up flow makes the condition of wastewater and homogeneous inoculums resulting in organic loading rate and wastewater rebellion time with an optimal cover.

Phase 1 with incubation for 14 days using batch feeding shows the volume of biogas that is still produced. Therefore, a combination of semi continuous method is applied to conventional digesters, UASB and CSTR. This method is used to determine the potential of biogas production in each digester. Incubation in phase 1 - phase 4 is done for 35 days. The combination of agricultural and livestock agro industrial wastewater in anaerobic process with batch and semi continuous method can produce biogas for 30-60 days [1] and [11].

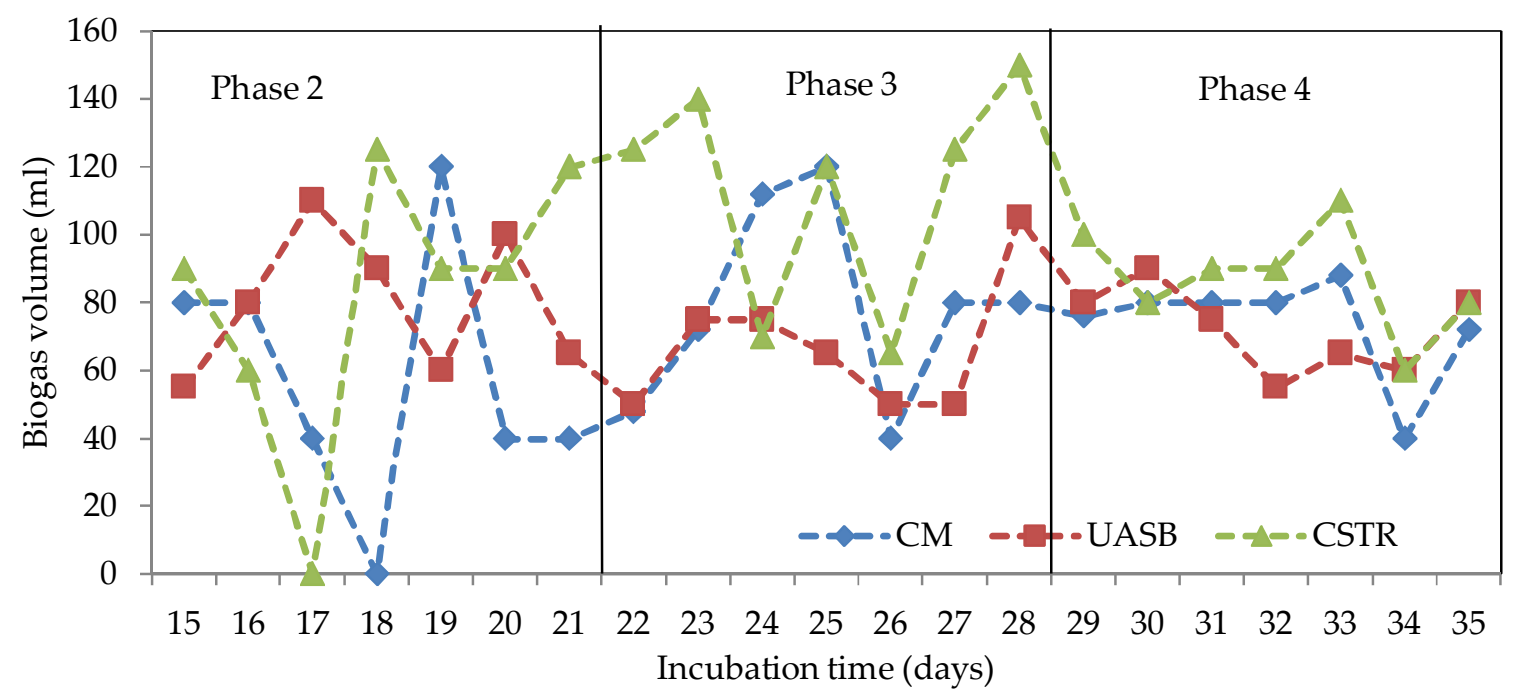

Figure 2. Fluctuation of biogas volume in semi - continuous method

The volume of biogas produced in each digester has a fluctuating value. The range of biogas volume values in Phase 2 - Phase 4 on conventional digesters, UASB and CSTR are respectively 0 - 120 $\mathrm{mL}, 50-115 \mathrm{~mL}$, and $0-150 \mathrm{~mL}$. In each of these phases is done in addition of substrate in the form of coffee wastewater containing high carbon that is $726-3,920 \mathrm{mg} / \mathrm{L}$. Stabilization of biogas production is done by replenishing cow manure as a source of nitrogen and methanogenic bacteria. This addition was predicted to lead to logarithmic stages in phases 3 - 4 based on the volume of biogas produced by 
CM, UASB, and CSTR in Figure 3. The volume of biogas produced is influenced by the construction of the digester. UASB and CSTR have an agitation system and are equipped with a temperature control system. Agitation can reduce biogas retained in biomass [12]. This makes UASB and CSTR digesters potentially produce greater biogas than conventional digesters. Average biogas production with incubation period of 35 days conventional digester, UASB and CSTR respectively were $69.90 \mathrm{~mL} /$ day, $83.57 \mathrm{~mL} /$ day and $83.14 \mathrm{~mL} /$ day. UASB has a more stable and greater performance in the production of biogas from coffee wastewater than conventional and CSTR. The anaerobic process using batch method in phase 1 and semi-continuous method in phase 2 - 4 shows that UASB produces stable biogas volume. Therefore, UASB is a more recommended digester in the processing of coffee wastewater based on the volume of biogas, the potential level of efficiency decrease waste pollution ease of operation and lower operational cost than CSTR.

\subsubsection{Biogas Composition}

The biogas composition comprises $50-70 \%$ of methane gas, $24-45 \%$ of carbon dioxide gas and $2-10 \%$ of other gases (sulfur, nitrogen, hydrogen, water vapor and ammonia) [13]. Anaerobic processes utilize elements of carbon and nitrogen to produce biogas. The result of biogas compositions on CM, UASB and CSTR which can be seen in Table 2.

Table 2. Biogas composition from coffee wastewater

\begin{tabular}{cc}
\hline Gas Types & Composition (\%) \\
\hline Methane Gas $\left(\mathrm{CH}_{4}\right)$ & $56.30 \pm 0.03$ \\
Carbon dioxide Gas $\left(\mathrm{CO}_{2}\right)$ & $34.33 \pm 0.02$ \\
Small Gas & $9.36 \pm 0.03$ \\
\hline Total & 100 \\
\hline
\end{tabular}

In the anaerobic process on conventional digesters, UASB and CSTR volume of $5 \mathrm{~L}$ (inoculums and coffee wastewater) resulted in a nearly uniform biogas composition for 35 days. The composition of biogas consists of $56.30 \pm 0.03 \%$ methane gas; $34.33 \pm 0.02 \%$ carbon dioxide gas and $9.36 \pm 0.03 \%$ of gases with a small volume. One of the things that give influence to the formation of biogas is the $\mathrm{C} / \mathrm{N}$ ratio. The $\mathrm{N}$ value (in $\mathrm{N}$ - Total) is smaller than the organic $\mathrm{C}$ value so that methane gas formation is less than optimal in the coffee wastewater. Optimum biogas composition is estimated to consist of methane gas $60-70 \%$ and about $20 \%$ of carbon dioxide and the remaining gas with a small volume. In addition, mesophilic conditions in the biogas formation process affect anaerobic processes that work in parallel which includes hydrolysis, acidification and methanonegenis. In mesophilic conditions hydrolysis process will produce $\mathrm{CO}_{2}$ and $\mathrm{H}_{2}$ compounds [7] that include hydrolysis, acidification and methanogenesis. In mesophilic conditions hydrolysis process will produce $\mathrm{CO}_{2}$ and $\mathrm{H}_{2}$ compounds that are not too much so that the formation of methane gas and carbon dioxide gas is less than optimal. The condition occurs because the anaerobic process will produce the optimum enzyme working on thermophilic conditions. In addition to the condition of thermophilic friction between particles occur rapidly so that affects the reshuffling of organic materials into methane gas.

\subsection{Analysis of Coffee Wastewater Parameters}

\subsubsection{Analysis of COD and BOD}

The parameters used for waste pollution levels based on oxygen content in water bodies to react chemically and biologically are COD and BOD expressed in mg/L. In general, COD and BOD indicate the content of decomposable organic materials. The higher value of the oxygen content in the waste is 
increasingly critical. Biodegradable organic materials affect the production of biogas in the anaerobic process.

Table 3. Value of COD efficiency

\begin{tabular}{cccc}
\hline \multirow{2}{*}{ Phase } & \multicolumn{3}{c}{ COD Efficiency (\%) } \\
\cline { 2 - 4 } & CM & UASB & CSTR \\
\hline 1 & $57.35 \pm 9.05$ & $52.00 \pm 6.36$ & $83.00 \pm 4.10$ \\
2 & $35.20 \pm 2.55$ & $22.00 \pm 2.86$ & $52.90 \pm 0.76$ \\
3 & $25.59 \pm 2.48$ & $61.00 \pm 0.93$ & $77.20 \pm 1.41$ \\
4 & $53.84 \pm 4.67$ & $85.00 \pm 0.34$ & $15.20 \pm 2.94$ \\
\hline
\end{tabular}

Table 4. Value of BOD efficiency

\begin{tabular}{cccc}
\hline \multirow{2}{*}{ Phase } & \multicolumn{3}{c}{ BOD Efficiency (\%) } \\
\cline { 2 - 4 } & CM & UASB & CSTR \\
\hline 1 & $57.42 \pm 9.00$ & $58.00 \pm 1.54$ & $60.90 \pm 2.69$ \\
2 & $41.36 \pm 0.90$ & $29.50 \pm 4.78$ & $50.60 \pm 2.46$ \\
3 & $42.12 \pm 0.94$ & $65.00 \pm 5.04$ & $64.30 \pm 4.39$ \\
4 & $13.90 \pm 4.67$ & $84.40 \pm 5.66$ & $14.10 \pm 6.29$ \\
\hline
\end{tabular}

Efficiency is a calculation to determine the digester's ability to degrade COD and BOD. The wastewater pollution loads indicated by the high COD and BOD values will accelerate the overhaul of organic materials [14]. Based on these conditions, it can be concluded that the high burden of pollution by coffee wastewater will accelerate the fermentation of organic materials in the anaerobic process so that the formation of methane gas is optimum. In addition, high values of COD and BOD will affect the speed of performance of methanogenic bacteria. This is due to the high level of pollution load that can reduce the amount of oxygen quickly in the coffee wastewater. In these conditions methanogenic bacteria can work optimally in the formation of biogas.

Reduction of COD and BOD by all three digesters has varying results according to Table 3 and 4. This reduction is influenced by the digester construction and feeding variation. CM can reduce the value of COD and BOD to reach $57.35 \pm 9.05 \%$ and $57.42 \pm 9.00 \%$. UASB digesters can reduce the value of COD and BOD up to $85.00 \pm 0.34 \%$ and $84.40 \pm 5.66 \%$. CSTR can reduce the value of COD and BOD up to $83.00 \pm 4.10 \%$ and $64.30 \pm 4.39 \%$. The ability to reduce COD and BOD is associated with high concentrations of organic matter. and the organic loading rate (ORL) [15]. The coffee wastewater used in this study has COD and BOD values with sequential values ranging from $3000-4450 \mathrm{mg} / \mathrm{L}$ and $2,016-2,800 \mathrm{mg} / \mathrm{L}$. In each digester there is an inoculums derived from the incubation of coffee wastewater and cow dung. The mixture of coffee wastewater and inoculums increase the value of COD and BOD presented at pollution load with the range of values 1,170 - 15,225 mg / $\mathrm{L}$ and 1,720 - 10,256 $\mathrm{mg} / \mathrm{L}$.

Conventional digesters, UASB and CSTR come from the same material that is fiber and feeding application that is processed by semi continuous method. The difference of the three digesters was (1) CM not equipped with a temperature control system, (2) UASB and CSTR digesters using automatic 
temperature control system, and (3) UASB digesters using flow as biomass mixing with $0.41 \mathrm{ml} / \mathrm{s}$ and CSTR using an automatic stirrer at $60 \mathrm{rpm}$. This difference influences the reduction of pollution loads as indicated by the COD and BOD values. UASB has the highest efficiency of pollution load reduction (COD and $\mathrm{BOD}$ ) of $85.00 \pm 0.34 \%$ and $84.40 \pm 5.66 \%$. This is due to the use of a temperature control system that can keep the temperature range of $31-35^{\circ} \mathrm{C}$. The temperatires process include mesophilic ones which tend to be ideal for anaerobic processes in the production of biogas and degradation of organic matter [4]. UASB has a blanket construction as a breeding ground for inoculums and has a digester up flow model. The design allows the adsorption of organic matter by optimal inoculums. Blanket is a place of inoculums with fixed construction and made in layers. This allows the insertion of wastewater with the inoculums to be homogeneous or the same. The use of $0.41 \mathrm{ml} / \mathrm{s}$ discharge allows mixing and contacting coffee wastewater with inoculums through the flow. Although CSTR is equipped with a temperature control system and the automatic mixer tends to be less effective for coffee wastewater treatment. This is due to the CSTR specification generally used for solid waste homogenization with particle size. In addition CSTR has a construction that requires additional energy for stirring, thus potentially increasing the operational costs higher than the UASB when it is applied. Variations of degradation of pollutants are also influenced by feeding variations.

Feeding variations affect the pollution load received by the CM, UASB, and CSTR. The pollution load approach is carried out by identifying the COD and BOD values of the mixture of coffee wastewater and inoculums. The values of $\mathrm{COD}$ and $\mathrm{BOD}$ of the mixture are received by conventional digesters were $4,372 \mathrm{mg} / \mathrm{L}-11,160 \mathrm{mg} / \mathrm{L}$ and 1,720 - 7,022 $\mathrm{mg} / \mathrm{L}$. The values of COD and BOD of the mixture received by UASB digesters were 3,433 $\mathrm{mg} / \mathrm{L}-15,225 \mathrm{mg} / \mathrm{L}$ and 2,732 - 10,256 $\mathrm{mg} / \mathrm{L}$. The values of COD and BOD mixture received by CSTR were 4,752 $\mathrm{mg} / \mathrm{L}-8,870 \mathrm{mg} / \mathrm{L}$ and 1,170 - 7,180 $\mathrm{mg} / \mathrm{L}$. Based on Table III and IV in general, anaerobic process with semi-continuous method shows that UASB digester has the best efficiency value in decreasing pollution load of coffee wastewater at $85.00 \pm 0.34 \%$ and $84.40 \pm 5.66 \%$. This condition is caused by feeding on UASB with a high pollution load giving the opportunity of methanogenic microorganism on blanket to multiply faster due to the availability of sufficient substrate [5].

\subsubsection{Analysis of $\mathrm{C} / \mathrm{N}$}

The $\mathrm{C} / \mathrm{N}$ ratio is a mathematical approach that used to determine the ratio of Carbon or $\mathrm{C}$ organic content as well as Nitrogen (N Total) in a substance. It is used to indicate the need for macronutrients used by methanogenic bacteria in the anaerobic process. Oxygen gas is used as a limiting factor in this process so that $\mathrm{C}$ and $\mathrm{N}$ elements are required as growth mediums of microorganisms or bacteria. Organic $\mathrm{C}$ is used to form carbon cells, volatile acids, methane $\left(\mathrm{CH}_{4}\right)$ and carbon dioxide $\left(\mathrm{CO}_{2}\right)$ gases, while $\mathrm{N}$ elements are used for nutrition or food and cell division in microorganisms that play a role in anaerobic processes [6]. Basically the value of $\mathrm{C}$ and $\mathrm{N}$ is used as bio fermentation in anaerobic process to produce methane gas as one of biogas component. In general, the formation of biogas requires $\mathrm{C} / \mathrm{N}$ of 15 - 30. A relatively high $\mathrm{C} / \mathrm{N}$ will increase the bacterial growth resulting in high carbon dioxide formers, whereas if the $\mathrm{C} / \mathrm{N}$ is low then nitrogen will accumulate to form ammonia gas.

In general, UASB digesters perform better than CM and CSTR in reducing C / $N$. The efficiency of $\mathrm{C} / \mathrm{N}$ reduction in UASB digesters by semi - continuous method averaged over $90 \%$. The degradation of organic matter in the form of $\mathrm{C}$ and $\mathrm{N}$ is influenced by the activity of bacteria Methanosarcina and Metanosaetain biogas production. UASB and CSTR digesters are equipped with a temperature control system so that the process temperature reaches $31-37^{\circ} \mathrm{C}$ and is good enough to reduce the $\mathrm{C} / \mathrm{N}$ level. This condition increases the performance of methanogenic bacteria to absorb $\mathrm{C}$ and $\mathrm{N}$. In addition mesophilic atmosphere $\left(25-40^{\circ} \mathrm{C}\right)$ can be an ideal enough condition to accelerate the rate of chemical reaction in the breakdown of organic matter [16]. This condition also occurs in conventional digester with a process temperature of $24.9-31^{\circ} \mathrm{C}$ with the highest $\mathrm{C} / \mathrm{N}$ reduction capability of $76.97 \pm 0.24 \%$ 
at Table 5. UASB is equipped with up flow for agitation with $0.41 \mathrm{~mL} / \mathrm{s}$ flow rate which encapsulates the incidence of fairly slow and uniform particle friction. This condition makes the insertion of coffee and inoculums wastewater in blanket with a long enough residence time so that $\mathrm{C} / \mathrm{N}$ reduction in UASB tends to be more optimal by the existence of methanogenic bacteria.

Table 5. Efficiency decreasing of $\mathrm{C} / \mathrm{N}$

\begin{tabular}{cccc}
\hline \multirow{2}{*}{ Phase } & \multicolumn{3}{c}{ C/N Efficiency (\%) } \\
\cline { 2 - 4 } & CM & UASB & CSTR \\
\hline 1 & $53.35 \pm 1.60$ & $93.88 \pm 5.36$ & $81.82 \pm 1.50$ \\
2 & $20.72 \pm 0.80$ & $86.03 \pm 6.56$ & $73.79 \pm 5.52$ \\
3 & $76.97 \pm 0.24$ & $97.78 \pm 0.57$ & $15.81 \pm 1.52$ \\
4 & $70.72 \pm 0.48$ & $96.97 \pm 2.19$ & $18.68 \pm 4.98$ \\
\hline
\end{tabular}

Feeding variation by semi continuous method influenced the organic material degradation level in $\mathrm{C}$ and $\mathrm{N}$. The conventional digester processes coffee wastewater with concentrations of $\mathrm{C}$ and $\mathrm{N}$ sequentially of $726-1,584 \mathrm{mg} / \mathrm{L}$ and $15.58-205.21 \mathrm{mg} / \mathrm{L}$. UASB digesters process coffee wastewater with concentrations of $C$ and $\mathrm{N}$ sequentially of 7,717 -1,584 mg / $\mathrm{L}$ and $15.58-88.72 \mathrm{mg} / \mathrm{L}$. The CSTR processes coffee wastewater with concentrations of $\mathrm{C}$ and $\mathrm{N}$ sequentially of $1584-3920 \mathrm{mg} / \mathrm{L}$ and $15.58-205.01 \mathrm{mg} / \mathrm{L}$. The incubation at the first feeding for 14 days shows a good value of drop efficiency based on Table 4 . In the second feeding, the three digesters experience the ability to reduce $\mathrm{C} / \mathrm{N}$. This condition is predicted to occur because the functional age of methanogenic bacteria is 10-12 days [9]. The third feeding was done by the addition of methanogenic bacteria from cow dung thus increasing the efficiency of $\mathrm{C} / \mathrm{N}$ value reduction on conventional and UASB digesters. The value of $\mathrm{C} / \mathrm{N}$ reduction efficiency in lower CSTR digesters was due to high $C$ concentrations and predicted a minimal methanogenic bacteria present. Therefore it is concluded that UASB digesters are more effective in the degradation of organic matter.

\section{Conclusions}

The coffee wastewater is corrosive because it has a low $\mathrm{pH}$ but has a high organic content. Anaerobic process is one method of coffee wastewater treatment to produce biogas and reduce the potential for pollution in water bodies. The management of coffee wastewater is done by semi continuous method with variation of feeding and variation of digester (Conventional Model, UASB and CSTR). The range of the temperature and $\mathrm{pH}$ values on the three digesters in the anaerobic process is $24.9-35^{\circ} \mathrm{C}$ and $6-8$. Based on the feeding and construction variations, UASB digesters have a stable performance in biogas production and reduction efficiency of $\mathrm{COD}, \mathrm{BOD}$ and $\mathrm{C} / \mathrm{N}$. The average biogas production of UASB digesters is $83.57 \mathrm{ml}$ / day. The highest remediation efficiency of COD, BOD and C/N by UASB digesters were $85.00 \pm 0.34,84.40 \pm 5.66$ and $97.78 \pm 0.57$.

Author Contribution: E. N, H.A.P and S.W conception and performed experimental design; H.A.P and M.W.S took data and formal analysis; E.N and S.W investigated, formed methodology and project administrator; B.M and M.W.S operated software. E.N supervised and provide the project; H.A.P wrote and finished original daft; E.N and H.A.P wrote the review and edited paper.

Funding: This research was funded by Indonesia Ministry of Research, Technology and Higher Education (Grant No. 0263/E5//2014). 
Acknowledgement: We gratefully acknowledge for University of Jember and Indonesia Ministry of Research, Technology and Higher Education in improving facility and donation to experiment. We also thanks the anonymous reviewers for their valuable comments that not only help us with the improvement of our manuscript, but suggest some neat ideas for future research and studies.

Conflict of Interest: The authors declare no conflict of interest.

\section{References}

1. E. Novita, "Biodegradability simulation of coffee wastewater using instant coffee," Agric. Agric. Sci. Procedia, vol. 9, pp. 217-229, 2016. DOI: 10.1016/j.aaspro.2016.02.138.

2. R. Rajagopal, N. Saady, M. Torrijos, J. Thanikal, and Y.-T. Hung, “Sustainable agro-food industrial wastewater treatment using high rate anaerobic process," Water, vol. 5, no. 1, pp. 292-311, 2013. DOI: 10.3390/w5010292.

3. F. C. Luz, S. Cordiner, A. Manni, V. Mulone, and V. Rocco, "Anaerobic digestion of liquid fraction coffee grounds at laboratory scale: evaluation of the biogas yield," Energy Procedia, vol. 105, pp. 1096-1101, 2017. DOI: 10.1016/j.egypro.2017.03.470.

4. A. Fontana et al., "Effects of geographic area, feedstock, temperature, and operating time on microbial communities of six full-scale biogas plants," Bioresour. Technol., vol. 218, pp. 980-990, 2016. DOI: 10.1016/j.biortech.2016.07.058.

5. H. A. Pradana, E. Novita, and S. Wahyuningsih, "Pollution bioremidiation for coffee wastewater using anaerobic process for biogas production," in IPB FW Great Event, 2016, pp. 96-108.

6. S. Aslanzadeh, K. Rajendran, A. Jeihanipour, and M. J. Taherzadeh, "The effect of effluent recirculation in a semi-continuous two-stage anaerobic digestion system," Energies, vol. 6, no. 6, pp. 2966-2981, 2013. DOI: 10.3390/en6062966.

7. A. F. Leite, L. Janke, Z. Lv, H. Harms, H. H. Richnow, and M. Nikolausz, "Improved monitoring of semicontinuous anaerobic digestion of sugarcane waste: Effects of increasing organic loading rate on methanogenic community dynamics," Int. J. Mol. Sci., vol. 16, no. 10, pp. 23210-23226, 2015. DOI: 10.3390/ijms161023210.

8. D. Nabarlatz, L. Arenas, D. Herrera, and D. Niño, "Biogas production by anaerobic digestion of wastewater from palm oil mill industry," Latinoam. J. oil, gas, Altern. energy, vol. 5, no. 2, pp. 73-84, 2013. ISSN: 0122-5358.

9. A. Schunurer and A. Jarvis, Microbiological Handbook for Biogas Plants. Swedish: Avfall Sverige and Swedish Gas Centre (SGC), 2009.

10. E. Novita, S. Wahyuningsih, and H. Andiananta Pradana, "Variation of Input Composition of Anaerobic Process on Coffee Wastewater Treatment," J. Agroteknologi, vol. 12, no. 01, pp. 43-57, 2018.

11. Y. E. Bombardiere, "The potential of anaerobic digestion technology to treat coffee waste in Huatusco, Mexico," Ohio University, 2006.

12. L. S. H. Ho, "First stage ad single stage continuously stirred tank anaerobic digestion of synthetic coplex wastewater and piggery wasterwater (with emphasis on thermoplhilic temperature," Murdoch University, 2010.

13. F. Gerlach, B. Grieb, and U. Zerger, Sustainable Biogas Production. Germany: FiBL Projekte GmbH, 2013.

14. E. G. . b c Junior, R. O. . d Jesus, A. C. . Ilva, J. R. . c Camargo, J. R. . Daniletto, and E. P. D. . f Coelho, "Comparative study on efficiency of biodigesters upflow anaerobic sludge blanket treating brewery effluent," Chem. Eng. Trans., vol. 38, pp. 157-162, 2014. DOI: 10.3303/CET1438027.

15. M. Muradin and Z. Foltynowicz, "Potential for producing biogas from agricultural waste in rural plants in Poland," Sustain., vol. 6, no. 8, pp. 5065-5074, 2014. DOI: 10.3390/su6085065.

16. N. Basset, C. Vidal, A. Coll, I. Fernández, and J. Dosta, "AnMBR technologies ( CSTR and UASB type ) for winery wastewater treatment at low temperatures," in SWWS, 2016, p. 12. 